\title{
O Polakach i Ukraińcach na Wołyniu w 1943 r. Kilka polemicznych uwag z okazji publikacji książki Bohdana Huda, Ukraińcy i Polacy na Naddnieprzu, Wołyniu i w Galicji Wschodniej w XIX i pierwszej połowie XX wieku, wyd. 2 rozsz. i uzup., Warszawa 2018, Pracownia Wydawnicza ElSet, ss. 445
}

Ostatnio ukazało się drugie, zmienione wydanie monografii Bohdana Huda, profesora Lwowskiego Uniwersytetu Narodowego im. Iwana Franki we Lwowie. Pierwsze wydanie, pod takim samym tytułem, które na polski rynek wydawniczy trafiło w 2013 r., gorąco rekomendowałem jako istotny głos w dyskusji o relacjach pomiędzy Polakami a Ukraińcami ${ }^{1}$. Jednak mając do wglądu tylko stosunkowo drobne fragmenty przygotowywanego nowego wydania tej książki, odmówiłem zgody na powtórzenie na okładce tamtej pozytywnej oceny. Mimo to $\mathrm{w}$ internecie praca prof. Huda jest reklamowana cytatem z mojej starej recenzji, tyle tylko że bez podawania nazwiska jej autora.

Jeżeli ktoś zada sobie trud porównania w obu wydaniach ostatniego, szóstego rozdziału zatytułowanego „Krwawe lata wojny”, zorientuje się, że w nowym jest to materiał o ponad dwukrotnie większej objętości. Mimo zachowania podobnej struktury wymowa obu tekstów jest odmienna. W pierwszym wypadku dotyczy on rzeczywiście tematu, któremu poświęcona została cała praca, a więc ukazaniu roli konfliktu ekonomiczno-społecznego, nazywanego

\footnotetext{
${ }^{1}$ B. Hud, Ukraińcy i Polacy na Naddnieprzu, Wotyniu i $w$ Galicji Wschodniej $w$ XIX i pierwszej połowie XX wieku, Lwów-Warszawa 2013. Fragmenty mojej recenzji z okładki.
} 
przez Autora w skrócie „walką o "ziemię»”, a wnioski sa adekwatne do zaprezentowanego materiału, natomiast w nowym wydaniu pojawiły się tam opinie i oceny w poprzednim tekście nieobecne, a znacznie wykraczające poza dotychczasowy temat monografii. Ponadto nadmierna objętość tekstu odbiła się negatywnie na stronie konstrukcyjnej rozdziału, powodując, że nawet dla specjalisty z zakresu omawianej w nim problematyki, za jakiego się uważam, stał się on nużący w czytaniu.

Twierdzę, że Autor miał rację, kładąc nacisk - jak to było w pierwszym wydaniu książki - na kwestie ekonomiczne, społeczne i wyznaniowe jako kluczowe przyczyny antagonizmu między Ukraińcami a Polakami na Wołyniu. Nie ulega dla mnie wattpliwości, że bez tego podłoża prawdopodobieństwo, że dojdzie na Wołyniu do masowych mordów na ludności polskiej, byłoby o wiele mniejsze. Obecnie jednak prof. Hud jeszcze bardziej niż wcześniej uwypukla rzekomą spontaniczność antypolskich wystapień, bo nie tylko podkreśla - jak poprzednio - niską liczebność wołyńskiej Ukraińskiej Powstańczej Armii (w okresie największego rozwoju ok. 6 tys. członków), ale eksponuje także relacje, z których wynika, że miejscowi działacze Organizacji Ukraińskich Nacjonalistów - nawet z kierowniczego aktywu tej organizacji - nie znali prac Dmytra Doncowa, co ma dowodzić, że obca im była ideologia ukraińskiego nacjonalizmu (s. 345), a banderowcami mogły się samowolnie nazywać „wszystkie pijaczki wioskowe” (s. 351) i to oni właśnie mordowali Polaków.

To oczywiste, że percepcja trudnych tekstów Doncowa przekraczała intelektualne możliwości większości członków OUN i UPA na Wołyniu i wystarczyło wyuczenie ich „Katechizmu ukraińskiego nacjonalisty”, ze słynnym „dekalogiem" będącym jego składową częścią. Masowe wydania broszury z tym „katechizmem” powielane były jeszcze w $1944 \mathrm{r}$. w polowych drukarniach, kiedy to banderowska OUN rzekomo się „demokratyzowała”. Broszury te stanowiły podstawę ideologicznego wychowania w OUN i UPA i pomagały osobom odpowiedzialnym za nie zaszczepiać fanatyczny nacjonalizm nawet wśród niepiśmiennych chłopów.

Twierdzenie, że na Wołyniu mamy do czynienia tylko ze zorganizowanymi przez ukraińskich nacjonalistów działaniami antypolskimi, a spontaniczne akcje ze strony chłopów ukraińskich nie występowały, byłoby czymś absurdalnym. Wiele napadów na pojedyncze osoby, rodziny, nawet części osad wtopionych we wsie ukraińskie mogło mieć taki charakter. Natomiast nikt - moim zdaniem - nie wykazał spontaniczności ukraińskich napadów na całe polskie osiedla. Zresztą nie znam masowych chłopskich wystapień całkowicie spontanicznych. Zawsze (nawet w rabacji galicyjskiej z 1846 r.) widoczne sa tam elementy organizacji czy inspiracji, odnotowane w źródłach. Ponadto wydarzenia z 1846 r. - przywoływane przez prof. Huda - są nieporównywalne z tym, co działo się na Wołyniu w 1943 r., bo czym innym jest niszczenie dworów i jego mieszkańców, a czym innym palenie i dokonywanie mordów na ludności całych osiedli. Nie mam wątpliwości, że masowe wystapienia 
na Wołyniu też były organizowane. Jest coraz więcej dostępnych źródeł ukraińskich wskazujących, że wiodąca rolę - przynajmniej od wiosny 1943 r., a więc od czasu, kiedy zaczęło się samodzielne niszczenie polskich osiedli (bez udziału Niemców) - w inspirowaniu mordów na Polakach odgrywały struktury banderowskiej OUN ${ }^{2}$. Z miesięcznego sprawozdania okręgowych władz OUN wiadomo, że masowe napady na osiedla polskie, mające miejsce w lipcu 1943 r. w powiatach włodzimierskim i horochowskim, były organizowane właśnie przez nie ${ }^{3}$. Istotną rolę w codziennym, systematycznym wyniszczaniu Polaków odgrywała Służba Bezpieki OUN, ogarniająca swoimi placówkami większość ukraińskich wsi na Wołyniu. Ona też nadzorowała mobilizowanie chłopów ukraińskich do napadów na polskie osiedla, zwłaszcza te, które pozbawione były elementów samoobrony. Jednym z szefów miejscowej SB OUN był Mykoła Kozak, ps. Smok (1914-1949), pisujący wiersze masowy morderca, nie tylko Polaków, ale także Ukraińców, „wynalazca” szczególnie drastycznych metod tortur stosowanych w trakcie przesłuchań podejrzanych ${ }^{4}$. Zgodnie z instrukcja „Smoka” bojówki SB mogły zabijać „Lachów” jako „wrogów narodu ukraińskiego” bez żadnych ograniczeń, a akcje „oczyszczania terenu z Lachów" miały być wykazywane w każdym sprawozdaniu z przeprowadzonych działań ${ }^{5}$. Natomiast banderowska UPA używana była do uderzeń na te miejscowości, gdzie spodziewano się polskiego zbrojnego oporu, toteż jej stosunkowo mała liczebność nie ma tutaj nic do rzeczy. Z niedawno odnalezionych nowych dokumentów OUN można wnioskować, że również działalność tzw. siekierników, czyli rzekomo samodzielnych grup chłopskich mordujących Polaków z użyciem narzędzi gospodarskich, wcale nie była spontaniczna, ale inspirowana i organizowana przez struktury OUN ${ }^{6}$.

Jako całkiem nowa teza pojawia się w drugim wydaniu książki prof. Huda stwierdzenie, że „charakter działań obu stron był bardzo podobny”, a tylko

\footnotetext{
${ }^{2}$ Największe kontrowersje budzi pierwszy większy mord na Wołyniu (w Parośli 9 II 1943 r.), dokonany na Polakach bez udziału Niemców. Sprawcami tej bestialskiej zbrodni, w której zginęło co najmniej 155 osób, była grupa podszywająca się pod partyzantów sowieckich, prawdopodobnie w celu skierowania polskich oskarżeń w tamtą stronę. Grzegorz Motyka w sposób jednoznaczny twierdzi, że zbrodni tej dokonała pierwsza sotnia banderowskiej UPA, dowodzona przez „Dowbeszkę”. Równie zdecydowanie część historyków ukraińskich neguje tę tezę. Tak czy inaczej, był to mord przemyślany i zorganizowany, ze spontanicznościa niemający nic wspólnego.

${ }^{3}$ G. Motyka, Zbrodnia Wotyńska 1943 roku i mit buntu ludowego, „Dzieje Najnowsze” 2016, nr 1 , s. 59 .

${ }^{4}$ D.W. Wiedieniejew, G.S. Bystruchin, Miecz i Tryzub. Rozwidka i kontrrozwidka ruchu ukrajinśkych nacjonalistiw ta UPA (1920-1945), Kijiw 206, s. 218-222, 363-364.

${ }^{5}$ Litopys UPA, Nowa serjia, t. II: Wolyń i Polissja 1943-1944. Dokumenty i materiaty, Kijiw-Toronto 1999, s. 422-423.

${ }^{6}$ M. Zajączkowski, „Sformować dywizje siekierników - postrach Lachów”. Przyczynek do genezy i charakteru akcji antypolskiej OUN-B i UPA w pierwszej połowie 1944 roku, „Pamięć i Sprawiedliwość" 2017, nr 1 (29), s. 545.
} 
„liczebna przewaga strony ukraińskiej była przyczyna znacznie większej ilości [liczby] akcji antypolskich" (s. 356-357). Autor twierdzi, że do takiej konstatacji upoważnia go analiza polskich archiwaliów, przy czym powołuje się na sprawozdanie miejscowych ogniw Delegatury Rządu z 31 I 1944 r., choć apogeum mordów ukraińskich na Polakach przypadło na wiosnę i lato $1943 \mathrm{r}$. W dokumencie jest mowa o tym, że polskie oddziały partyzanckie w wypadach na wsie ukraińskie „przepędzaja z nich Ukraińców, zabieraja inwentarz, a całe osiedla pala. Tych spośród Ukraińców, którzy nie zdołaja zbiec, strzelają na miejscu, nie wyłączając podobno [podkreślenie - A.S.] kobiet i dzieci” (s. 356). Raport ten - cytowany zresztą w pierwszym wydaniu książki, tyle tylko że bez tej nowej interpretacji - ewidentnie dotyczy działań podejmowanych w celu przygotowania bazy dla koncentracji oddziałów przyszłej 27 Wołyńskiej Dywizji Piechoty AK. Sa one znane i omawiane w literaturze przedmiotu $^{7}$ i miały miejsce w czasie, gdy polska ludność wiejska, jeżeli nie uciekła lub nie schroniła się w ośrodkach samoobrony, to na przeważającej części terytorium Wołynia została już wymordowana.

Gdyby teza o „podobieństwie” działań obu stron była prawdziwa, to prof. Hud powinien wymienić dokonane przez stronę polska wiosną i latem 1943 r. na Wołyniu akcje analogiczne do ukraińskich, czyli równoczesne napady na co najmniej kilka czy kilkanaście wiosek, których jedynym celem było wymordowanie całej ich ludności, zwłaszcza kobiet i dzieci, takie jak chociażby przeprowadzone przez Ukraińców ok. 11 VII $1943 \mathrm{r}$. w powiecie włodzimierskim i horochowskim czy 29 VIII 1943 r. w rejonie Ostrówek i Woli Ostrowickiej. Jak dotąd historiografia ukraińska takich skoordynowanych działań polskich prowadzonych w $1943 \mathrm{r}$. nie wskazała, a co najwyżej zaprzecza, że w akcjach inicjowanych przez OUN chodziło o wymordowanie wszystkich Polaków ${ }^{8}$.

Oczywiście, trudno historykowi, jeżeli kieruje się zasadą obiektywizmu, negować fakty świadczące o tym, że także Polacy niszczyli wsie ukraińskie, zwłaszcza wówczas, gdy po fali największych rzezi dokonanych przez Ukraińców skupiali się w miejscowościach przygotowywanych jako punkty oporu, np. w Przebrażu czy Hucie Stepańskiej. Powstały w wyniku tych akcji pas „ziemi niczyjej" ułatwiał bowiem obronę przed niespodziewanym atakiem oddziałów UPA, a ponieważ dokonywano także wypadów po żywność dla chronionych tysięcznych rzesz uchodźców, ofiarami tych wszystkich napadów stawali się wieśniacy, którzy z działaniami antypolskimi mogli nie mieć nic wspólnego. Aktom tym towarzyszyły wypadki morderstw i okrucieństw.

\footnotetext{
7 A.L. Sowa, Kto wydat wyrok na miasto? Plany operacyjne ZWZ-AK (1940-1944) $i$ sposoby ich realizacji, Kraków 2016, s. 221-225. Tutaj też podstawowa literatura dotycząca działań 27 Wołyńskiej DP AK, w tym również tego zagadnienia.

${ }^{8}$ W. Wiatrowycz, Za łasztunkamy „Wotyni-43”. Newidomapolśko-ukrajinśkawijna, Charkiw 2016, s. $146-149$.
} 
Przy korzystaniu z niezwykle krytycznych, a na ogół mało konkretnych, sprawozdań Kazimierza Banacha „Linowskiego” na temat działalności oddziałów AK na Wołyniu, którymi prof. Hud obficie podbudowuje swoje tezy, warto pamiętać o istnieniu bardzo ostrego konfliktu personalnego pomiędzy nim, jako delegatem Rządu RP na okręg wołyński, a komendantem wołyńskiego okręgu AK płk. Kazimierzem Bąbińskim. Jednym z powodów powstawania tych raportów było dążenie do usunięcia rywala z dowodzenia wołyńską AK. Zreszta Banach przebywał od sierpnia 1943 r. głównie w Warszawie, na Wołyń jeździł sporadycznie, od czasu do czasu wizytujacc ten teren.

Chęć udowodnienia własnych tez prowadzić może także do błędów warsztatowych. W przypisie do zdania: „W czasie konfliktu na Wołyniu [...] formacje polskie [...] stosowały [...] nie mniej okrutne metody walki" (s. 354) jest odniesienie do nasyconego niezwykłym sadyzmem przytoczonego cytatu ze wspomnień Stefana Dąmbskiego. „Egzekutor” ten działał jednak na terenie Rzeszowszczyzny i z Wołyniem jako żywo nic wspólnego nie miał.

$\mathrm{W}$ innym miejscu cytowane za historykiem ukraińskim informacje o napadach na wsie ukraińskie „z udziałem Polaków” w kolejnym zdaniu tekstu prof. Huda przekształcają się już jednoznacznie w „napady polskie” (s. 360).

Praktyka, która pojawia się $\mathrm{w}$ drugim wydaniu pracy, jest przytaczanie dokumentów z podawaniem sygnatur archiwalnych (tak jakby Autor był pierwszym badaczem, który do nich dotarł) w sytuacji, kiedy te same materiały zamieszczone $\mathrm{w}$ pierwszym wydaniu książki cytowano za publikacja ukraińskiego historyka Ihora Iljuszyna9.

Porównanie przez Autora granicy między Komisariatem Rzeszy Ukraina a Dystryktem Galicja wchodzacym w skład Generalnego Gubernatorstwa do tzw. kordonu sokalskiego z okresu II RP (s. 332) jest nietrafne (delikatnie to określając), gdyż tzw. kordon sokalski izolował Wołyń od działalności ukraińskich organizacji politycznych i gospodarczych majacych swoje centrale we Lwowie i utrudniał kolportaż wydawanej tam prasy ukraińskiej, natomiast w żaden sposób nie ograniczał poruszania się osób, a tym bardziej przepływu towarów. W okresie okupacji niemieckiej była to natomiast normalna granica celna i obowiązywał zakaz ruchu ludności niemajacej specjalnych przepustek.

Czy okrucieństwo ukraińskich chłopów na Wołyniu opisywane w źródłach z lat wojny to tylko przesada, co sugeruje prof. Hud, sprowadzając problem do mordowania narzędziami gospodarskimi oraz podkreślając, że to kwestia uniwersalna, ponadnarodowa? (s. 353). W trakcie swoich obecnych kwerend, niemających nic wspólnego ze sprawami ukraińskimi, znalazłem w „Ilustrowanym Kurierze Codziennym” z 19 III 1939 r. (s. 14) notatkę zatytułowana „Gorsi od zwierząt! Wstrząsający alarm nauczycielki z Wołynia”. Nauczycielka

\footnotetext{
${ }_{9} \mathrm{Na}$ przykład przypisy 45 (s. 343) i 90 (s. 356) w nowym wydaniu książki. Odpowiednio w wydaniu z 2013 r. przypisy 30 (s. 319) i 70 (s. 329).
} 
szkoły powszechnej ze wsi Adamczuki ${ }^{10}$ wystosowała pismo do towarzystwa opieki nad zwierzętami w Warszawie, „pismo budzące grozę”. Wstrząśnięta autorka opisała rozrywki miejscowych chłopów. Jeden z gospodarzy dla zabawy obcią skrzydła sroce i puścił ją wolno, inny z tych samych powodów uwiazał na sznurku ptaka do gałęzi drzewa. „Przy tych «zabawach» asystowała niemal cała ludność wsi. Na męczarnie stworzeń patrzą dzieci; wyjmują tam żywym ptakom oczy, obcinają nogi”. Psy łańcuchowe nie są żywione po kilka dni. Jeden pies na łańcuchu zdechł z głodu. „Pewien gospodarz wetkną kotu pod ogon rozstrzępione drewno. Kot $\mathrm{z}$ bólu chciał uciec przez dziurę w strychu lecz zaczepił o drewno i tak wiszac zdychał przez trzy dni”. Autorka prosiła o pomoc. Takie postępowanie nie było więc chyba „normą” dotycząca powszechnych zachowań chłopskich w tamtych latach, skoro tu wywołało reakcję pełną oburzenia i wstrętu.

Oczywiście także polska historiografia nadal nie jest wolna od metodologicznych słabości. Widać je zwłaszcza - na co Autor słusznie zwrócił uwage (s. 361-362) - w swoistej licytacji między historykami co do liczby polskich ofiar tego niezwykle krwawego i okrutnego konfliktu, która w różnych wypowiedziach ciagle rośnie, mimo braku jakichkolwiek podstaw źródłowych czy zastosowania nowych technik badawczych uprawniających do takich wnioskowań ${ }^{11}$.

Zasadniczym problemem rzutującym na jakość dyskursu między historykami polskimi i ukraińskim jest fakt, że - jak dotąd - w historiografii nie ma monografii, która w sposób wyczerpujący, merytoryczny i bez zastrzeżeń warsztatowych prezentowałaby całą historię Wołynia w latach 1939-1944, z wykorzystaniem źródeł polskich, ukraińskich, niemieckich i sowieckich. Opublikowane dotąd prace, w tym najpoważniejsze z nich, autorstwa Władysława Filara, dalekie są od tego ideału. Niestety obecnie nie ma, jeżeli moja wiedza jest pełna, także w Polsce historyka, który prowadziłby badania pozwalające sądzić, że ta niezwykle istotna luka w historiografii zostanie w przewidywalnym czasie zlikwidowana. Oczywiście ideałem byłoby, gdyby taka pracę napisał jakiś historyk z zewnątrz, osobiście niezaangażowany w spory polsko-ukraińsko-rosyjskie. Dopóki taka praca się nie ukaże, w przestrzeni publicznej ciagle pojawiać się będą wypowiedzi i publikacje zawierające

${ }^{10}$ Prawdopodobnie chodzi o wieś przed wojną należącą do gminy Pulemiec, pow. Luboml. Resztki tej wsi, położonej tuż nad samym Bugiem, istnieją do dzisiaj.

${ }_{11}$ Za oparte na najbardziej racjonalnych podstawach uważam szacunki Grzegorza Hryciuka, zamieszczone w monografii Przemiany narodowościowe i ludnościowe w Galicji Wschodniej i na Wotyniu w latach 1931-1948, Toruń 2005, s. 282, 315. Oscylują one między 70 a 85 tys. Polaków zamordowanych przez nacjonalistów ukraińskich na całych kresach południowo-wschodnich II RP. W książce jest także opis przyjętej przez autora metody badań. Według ukraińskich szacunków do lipca 1944 r. na całym terenie objętym konfliktem polsko-ukraińskim miało zginać 38-39 tys. Polaków (W. Wiatrowycz, op. cit., s. 215). Nie jest jasne, na jakiej podstawie ustalono taką liczbę pomordowanych. 
różnorakie tezy wartościujące i stygmatyzujące, oparte na dowolnie dobieranym materiale źródłowym.

W województwach II RP zamieszkanych przez Białorusinów głód ziemi był jeszcze większy niż na Wołyniu, chociażby z powodu gorszej jakości tamtejszej ziemi. Konflikt społeczny był tam nie mniej silny niż na ziemiach zamieszkałych przez Ukraińców. Ludność białoruska miała podobnie negatywne doświadczenia, jak ukraińska, ze swoich relacji z polską administracja czy ziemiaństwem. W okresie rządów sanacji polskie władze w sposób bezwzględny niszczyły wszystkie przejawy życia białoruskiego - dość stwierdzić, że w 1939 r. nie było ani jednej szkoły powszechnej z białoruskim językiem nauczania. W trakcie kampanii 1939 r. bandy złożone z Białorusinów, podobnie jak na terenach zamieszkanych przez Ukraińców, dokonywały napadów na Polaków - ziemian i wojskowych osadników. A jednak w latach okupacji niemieckiej nie doszło na Nowogródczyźnie, Wileńszczyźnie czy Białostocczyźnie ani do większych „spontanicznych” napadów, ani do masowych mordów ludności polskiej z próbą jej całkowitej eksterminacji. I to mimo faktu, że wszystkie czynniki sprzyjajace temu, podobne do tych na Wołyniu, tam również wystapiły. Tam także Polacy byli administratorami sowchozów przekształconych w Liegenschafty, mordowano Żydów, masowo rozwijała się partyzantka sowiecka dokonująca prowokacji wymierzonych w „białopolaków”, miały miejsce niemieckie ekspedycje karne połączone z krwawymi pacyfikacjami białoruskich wsi, na podstawie wzajemnych polskich i białoruskich donosów tysiące ludzi zostały zabite przez Niemców, administracja niemiecka najpierw opierała się na powszechnie zatrudnianych w urzędach Polakach, a następnie faworyzowała prawosławnych Białorusinów kosztem Polaków katolików $^{12}$. Skoro więc sytuacja wyglądała analogicznie, to dlaczego nie było tam prób wymordowania polskich włościan oraz szlachty zaściankowej przez większość białoruską? Stwierdzenie, może prawdziwe, że chłop białoruski nie miał w sobie tej dozy okrucieństwa co chłop wołyński, niczego nie wyjaśnia.

Jedno jest pewne - nie działała wśród Białorusinów taka organizacja, jak OUN, która popularyzowała wśród swoich zwolenników doktrynę opracowana przez jednego z jej przedwojennych czołowych działaczy, Mychajłe Kołodzińskiego. Wpisano w nia, jako jeden z celów działań, chęć wyniszczenia „na ukraińskich terenach etnicznych” mniejszości narodowych, w pierwszym rzędzie Polaków. Dokonać tego miały masy chłopskie. Jak pisał Kołodziński w nielegalnej broszurze Powstanie polskie $1863 \mathrm{r}$., wydanej we Lwowie

\footnotetext{
12 J. Turonek, Białoruś pod okupacja niemiecka, Warszawa-Wrocław 1989; E. Mironowicz, Wojna wszystkich ze wszystkimi. Białoruś 1941-1944, Kraków 2015. Swego czasu uczestniczył w pacyfikacjach na terenie wschodniej Białorusi także batalion policji ukraińskiej, w którym trzon szeregowych i oficerów stanowili nacjonaliści ukraińscy. Dowódcą kompanii tego oddziału był Roman Szuchewycz, w połowie 1943 r. głowa „Prowodu” OUN i główny komendant UPA. Policjanci tego oddziału w ciagu 10 miesięcy przy stracie 49 funkcjonariuszy zabili ponad 2 tys. ludzi. E. Mironowicz, op. cit., s. 60-61.
} 
w 1929 r. nakładem „Biblioteki Nacjonalistycznej”: „Trzeba krwi - dajmy morze krwi. Trzeba terroru - uczyńmy go piekielnym. Trzeba poświęcić dobra materialne - nie zostawmy sobie niczego. Mając na celu wolne państwo ukraińskie, idźmy doń wszystkimi środkami i wszystkimi szlakami. Nie wstydźmy się mordów, grabieży, podpaleń. W walce nie ma etyki! Etyka na wojnie, to pozostałości niewolnictwa, narzucone przez zwycięzców zwyciężonym. Nie dbajmy o dobre imię i opinię w świecie, gdyż zawsze będą nas nazywać bandytami, choćbyśmy nie wiadomo jak byli ideowymi. Każda droga, która prowadzi do naszego najwyższego celu, bez względu na to, czy nazywa się ona u innych bohaterstwem czy podłościa, jest naszą droga" ${ }^{13}$. Uważam, że działania podjęte wobec Polaków w 1943 r. na Wołyniu doskonale pasują do amoralnych wytycznych tej broszury. Także we wspomnianym już powyżej „Katechizmie ukraińskiego nacjonalisty” kładziono nacisk na to, że jedynym kryterium, jakim należy się kierować $\mathrm{w}$ podejmowanych działaniach, jest wyłącznie „dobro narodu”.

Podsumowując - uważam drugie wydanie pracy prof. Huda zarówno pod względem klarowności wywodu, jak i przesłania za znacznie mniej udane od pierwszego wydania. Pojawiły się tam tezy bardzo kontrowersyjne, w jakimś sensie przesłaniające swoja wagą nawet te argumenty, które - jak sądzę nadal zasługują na poważne potraktowanie.

${ }^{13}$ R. Wysocki, Organizacja Ukraińskich Nacjonalistów w Polsce w latach 1929-1939. Geneza, struktura, program, ideologia, Lublin 2003, s. 185. 